SECTION 29. Literature. Folklore. Translation Studies.

Oksana Victorovna Marunevich

$\mathrm{PhD}$ in Linguistics, Assistant Professor, Assistant Professor

Rostov State Transport University, Russia

oks.marunevich@maul.ru

\title{
LINGUISTIC IMAGE OF AN IRISHMAN IN THE CONTEXT OF HISTORIC REFLECTION
}

\begin{abstract}
The article constructs a stereotypical image of an Irishman, existing in the British national memory form the XII century till nowadays. The analysis of ethnic phraseological units showed that they fix fewer positive qualities of the Irish. To a greater extent they show disrespectful and derogatory attitude towards this ethnic group. The resulting portrait is confirmed by data of memoirs and official historical chronicles.

Key words: ethnic identity, stereotype, phraseological unit, national historical memory, connotative meaning.

\section{ЛИНГВИСТИЧЕСКИЙ ОБРАЗ ИРЛАНДЦА КОНТЕКСТЕ ИСТОРИЧЕСКОЙ РЕФЛЕКСИИ}

Аннотация: $B$ статье конструируется стереотипный образ ирландияа, существуюший в английской национально-исторической памяти с XII в. по сегодняшний день. Лингвистический анализ энтофразеологизмов показал, что они меньшей степени фиксируют положительнье качества ирландчев. Гораздо большее отражение находит неуважительное и уничижительное отночение к данной этнической группе. Полученный портрет подтверждается данными публицистики, мемуаристики и официальных исторических хроник.

Ключевые слова: этническое самосознание, стереотип, фразеологическая единица, национально-историческая память, коннотативное значение.

Одним из важных элементов структуры национального самосознания является историческая память, под которой понимается накопленная в ходе социальноисторического развития этноса информация, зафиксированная в результатах практической и познавательной деятельности.

Еще Платон высказал мысль о том, память - это припоминание бессмертной душой того, что она некогда видела [3, с. 43]. Однако впервые в научный обиход термин историческая память был введен Я.К. Ребане. Историческая память - это совокупность ненаследственных социально-культурных средств и систем информации, на основе которых формируются: психика и сознание человека как исторически конкретного существа, выступающего также и в качестве субъекта познания; осуществляется исторически развивающийся процесс человеческого, т.е. общественного сознания [4, с. 4454].

Необходимость исследования исторической памяти вызвана во многом тем, что собственно сам данный феномен крайне неоднозначен. С одной стороны, он может быть использован для эскалации этнических конфликтов, с другой - укреплять сотрудничество и связи между народами. Таким образом, этнический фактор является одной из главнейших детерминант исторической памяти. Представления, знания, оценки исторического прошлого со стороны индивидуума, группы, общества основываются на событиях, явлениях, отражающих их конкретно-этническую специфику. 
Историческая память сохраняется при помощи четырех механизмов: иконографические или кинематографические зрительные образы, социальное действие, воспроизводящее память через определенные навыки, от субъекта к объекту. Однако для нашей работы актуальным представляется анализ образа ирландца посредством использования таких механизмов, как устная (антропологическая) традиция, соотносимая в языкознании с народным творчеством, и тексты, художественные и мемуарные. При этом справедлива мысль М. Холбвоша о том, что достаточно сложно провести резкую границу между памятью, которая прямо ассоциируется с устным народным творчеством, и модернизированными репрезентациями, которые понимаются как нечто, подвергшееся влиянию научной историографии) [7, p. 23].

Тем не менее, лингвистическим выражением исторической памяти является именно фольклор, мемораты, национальная литература, пословицы, поговорки, фразеологизмы и т.д. Лингвострановедческая ценность фразеологических словосочетаний, содержащих компонент, обозначающий национальность не вызывает сомнений. Это маленький фрагмент того пласта лексики, который может рассказать о важных вехах в истории народа, чертах его характера, кулинарных пристрастиях и др. И, действительно, уже само наличие в составе рассматриваемых единиц компонента Irish и его производных (Irishman, $P a d d y)$ указывает на этнокультурную специфику и выполняет своеобразную идентифицирующую функцию. В связи с этим, нам удалось классифицировать их следующим образом:

1) фразеологизмы, подтверждающие стереотипные представления о характере ирландцев:

- агрессивность: to get somebody's Irish up - разгневать, разозлить кого-либо; Irish confetti - камни и другие тяжелые предметы, которыми бросаются во время демонстраций и беспорядков, обломки кирпичей; paddy-whack - сильный, яростный удар; to weep Irish начинать беспорядки; Irish kiss - синяк под глазом, Irish glasses - синяки под обоими глазами. Следует отметить, что с точки зрения народной этимологии из-за фонетического влияния слова ire (гнев) название страны Ireland обозначает «страну гнева».

Агрессивность и задиристость ирландцев стала основой ряда этнических анекдотов: К дерущимся возле паба ирландиам подходит человек и интересуется: частная ли это драка или в ней могут участвовать все? По представлениям англичан драка является основным методом разрешения разногласий у ирландцев, поэтому они часто оказываются за решеткой. По статистике в XIX веке 55 \% всех арестованных в Нью-Йорке в день - лица ирландского происхождения [5]. Язык чутко реагирует на все социальные явления, поэтому в названии здания полицейского участка и полицейского автомобиля присутствует компонент Irish - Irish clubhouse и Irish picnic wagon соответственно.

- лживость: Irish evidence - лжесвидетельство. Однако данная фразеологическая единица своим происхождением обязана не природной лживости ирландцев, а их нежеланием выдавать английским властям собратьев-мятежников во время мятежей 1641 и 1798 гг.

- своеобразное чувство юмора: считается, что ирландцы грубоваты, склонны к «черному юмору», поэтому Irish comics - это вовсе не нечто занятное, а некрологи в газете.

- неряшливость: Irish wash - смена одежды вместо умывания; Irish shave - не бритый; Irish curtain - паутина внутри дома.

- глупость: В современном английском сленге собственно этноним Irish имеет переносное значение - абсурдность, глупость, а устойчивое выражение Irish bull означает противоречие, нелепицу.

- о религиозности ирландцев может свидетельствовать фразеологизм Irish / Irishman's dinner - пост. Однако как нам кажется, он скорее будет репрезентацией бедности ирландцев, также как и выражения Irish steak - сыр и Irishman's pocket - пустые карманы, безденежье. 
- в сленговых фразеологизмах помимо всего вышеперечисленного содержится аллюзия на сексуальную несдержанность ирландцев: Irish wedding - оргия; Irish toothache нежелательная беременность.

2) Фразеологические единицы, указывающие на пристрастие ирландцев к крепким алкогольным напиткам: Irish horse - подсоленное пиво; Irish pop - пиво с виски; Irish cream - виски; Irish mist - виски в сочетании с вином; Irish velvet - кофе, где больше виски, чем кофе; Irish milk - темное ирландское пиво; Irishman's four-course meal- четыре пинты пива «Гиннес».

3) Кроме того, среди выявленных характеристик ирландцев следует отметить их антонимичность. Так, выражение Irishman's rise/promotion означает отнюдь не повышение по службе, а напротив урезание зарплаты. Данная идиома восходит корнями к XIX в., когда ирландцев неохотно брали на работу. Оскорбительные объявления - "No Irish need apply", говорят о том, что к ним относились как к людям второго сорта. Основываясь на этом факте можно прийти к ошибочному выводу, что ирландцы - не везучий народ. Однако, фразеологическая единица Irish luck означает невероятное везение. Кроме того, веселым ирландцам свойственен крайний пессимизм: Irish sulk - депрессия. Противоречивость утверждений, содержащихся в данных фразеологических единицах, объяснятся неоднородностью субъектов, выступающих в качестве носителей оценочных норм, наличием различных мотивировок оценки и оценочных стереотипов [1, с. 13].

4) Язык может рассказать о гастрономических пристрастиях его носителей. Основным продуктом питания ирландцев является картофель. Поэтому не случайно существует множество названий этого продукта: Irishman's friend, Irish apricot, Irish grape, Irish plump, Irish apple, Irish gem, Irish football, Irish root, Irish apple. О важности картофеля в жизни ирландцев свидетельствует тот факт, что неурожаи картофеля в 1845-1849 гг. названы в истории Ирландии Великим голодом (Great Famine). Объясняя причины голода Дж. Рифкин писал: The Celtic grazing lands of... Ireland had been used to pasture cows for centuries. The British colonised... the Irish, transforming much of their countryside into an extended grazing land to raise cattle for a hungry consumer market at home... Eventually, cows took over much of Ireland, leaving the native population virtually dependent on the potato for survival [10, c. 56-57].

5) В некоторых устойчивых словосочетаниях с лексемой Irish заключены так называемые отсубъектные характеристики ирландца, являющиеся отражением не самого представителя данного этноса, а оценки и отношения к нему. Оценка эта выражается понятиями «поддельный», «дешевый», лишь чем-то напоминающий предмет настоящий: Irish baby buggy - тачка; Irish banjo - лопата, совок; Irish hurricane - штиль; Paddy's lantern - луна.

При этом, этноним Irish несет большую коннотативную нагрузку. По мнению Е.Л. Березович и Д.П. Гулик, «причины образования определенных коннотаций у этнонимов носят экстралингвистический характер: они связаны с историческим, политическим, религиозным и психологическим контекстом существования данных лексем и их референтов» [2, с. 252].

В этой связи следует отметить, что этнические предрассудки по поводу ирландцев самое раннее проявление английской мегаломании, согласно которой англичане - выше любого другого этноса.

Сложившееся у англичан представление об ирландцах как о низшей расе восходит к XII в. - времени завоевания Ирландии норманнской феодальной знатью. Однако еще до норманнского завоевания в своих воспоминаниях местные церковники подчеркивали греховность и порочность ирландцев. Так, Малахи Армагейский писал: To the beasts, but not to the people he was sent. So profligate in their morals, so uncouth in their ceremonies, so impious in faith, so barbarous in laws, so rebellious to discipline, so filthy in life, Christian in name, but Pagans in reality [цит. по: 8, p. 11]. 
Сходное мнение также находим у Джеральда Валлийского: Irishes live far from wellbehaved and dutiful people ... They live on beasts only, and live like beasts [6, p. 18]. Работе Джеральда суждено было формировать отношение англичан к ирландцам еще на протяжении нескольких столетий. Первоначально с его трудом могли ознакомиться лишь представители узкого круга избранных, т.к. писал он по-латыни, книгопечатание еще не было изобретено. Но в период правления королевы Елизаветы I книга была издана в английском варианте, что совпало с дальнейшими действиями Англии по завоеванию Ирландии.

В 1577 г. появляются первые сочинения об истории Ирландии на английском языке, собранные «Хронике» Холиншеда. Историографии, написанные Э. Кэмпом и Р. Стэнихерстом, изображают ирландцев варварами и отсталым народом. Всевозможные оправдания колонизации были собраны и тщательно обработаны Э. Спенсером в книге «О государстве ирландском» (1596). В данной работе Э. Спенсер дал ирландцам следующую характеристику: Marry those be the most barbaric and loathy conditions of any people (I think) under heaven... They do use all the beastly behaviour that may be, they oppress all men, they spoil as well the subject, as the enemy; they steal, they are cruel and bloody, full of revenge, and delighting in deadly execution, licentious, swearers and blasphemers, common ravishers of women, and murderers of children [цит. по: 9, p. 12].

Проанализировав лексический состав фразеологизмов с лексическим компонентом Irish, мы обнаружили, что они служат источником для выявления характерных черт ирландского этноса в национальном сознании англичан. Интерес к этническим фразеологизмам английского языка объясняется тем, что они отражают стереотипные суждения об ирландцах, закрепившиеся в языке в ходе политического, экономического и культурного взаимодействия Великобритании с Ирландией, начиная с XII в.

\section{References:}

1. Бабаева Е.В. Культурно-языковые характеристики отношения к собственности (на материале немецкого и русского языков): Автореф. дис. канд. филол. наук: 10.02.20. Волгоград, 1997.

2. Березович Е.Л., Гулик Д.П. Ономасиологический портрет «человека этнического»: принципы построения и интерпретации // Встречи этнических культур в зеркале языка в сопоставительном лингвокультурологическом аспекте. М.: Наука, 2002. - С. 232-253.

3. Платон. Государство. М., 1971. Т. 1.

4. Ребане Я.К. Информация и социальная память// Вопросы философии. 1982. № 8. С. 44-54.

5. Ethnic enclaves of New York [Электронный ресурс]. Режим доступа: http://www.nyc.gov

6. Gerald of Wales. The History and Topography of Ireland. Penguin Classics, 1982.

7. Hallbwash M. The Collective Memory Cambrige University Press, 1950.

8. Jackson T.A. Ireland Her Own. An Outline History of the Irish Struggle for National Freedom. Dublin, 1982.

9. Lebow N. British Historians and Irish History // Eire-Ireland. Vol. VIII. № 4. 1973. - pp. 3-38.

10. Rifkin J. Beyond Beef. Plume, 1993. 